\title{
The Literacy Preparation in Turkish Preschool Education
}

\author{
Semra Tican Başaran \& Sabri Sidekli \\ Muğla Sitkı Koçman University, Turkey
}

\begin{abstract}
The purpose of this study is to reveal the views and recommendations of the preschool and primary school teachers on the literacy preparation in Turkish preschool education. The study is designed as phenomenological research. The participants of the study are 12 preschool and 9 primary school teachers who have been teaching actively in the western part of Turkey. The qualitative data was collected through face-to-face interviews and analyzed through content analysis. The findings of the study show that preschool teachers have some confusion on literacy preparation and readiness. While preschool and primary school teachers are of the same opinion about the need for literacy preparation in preschool education, they have different opinions about the literacy preparation activities conducted in preschool education. While preschool teachers think that they get preschoolers ready for literacy, primary school teachers think that first graders in their classes do not come literately ready from preschool education. Teachers participated in the study; think that the lack of collaboration among preschool and primary school teachers, some deficiencies in preschool education curriculum and in the education system, and the preschool teachers' imperfect knowledge in the literacy readiness are the possible reasons of inadequacy of readiness for literacy in preschool education. They recommend systematic collaboration among teachers, review of preschool education curriculum and providing professional support for preschool teachers to support literacy readiness in preschool education.
\end{abstract}

Keywords: Literacy; Literacy Preparation; Preschool Education; Preschool Teacher; Primary School; Primary School Teacher.

\section{Introduction}

Preschool education years can be described as "miracle years" (Oktay, 1999) that have high profits for both children and the society in which they live (Carneiro \& Heckman, 2004). In this period, a powerful beginning, thanks to quality education, can lead to a better life (Kagan \& Zigler, 1987); and it is a good investment in terms of economy (Hanushek \& Wößmann, 2010). Early childhood acquisitions can affect the later learning processes because learning supports skills improvement and skills improvement supports learning (Heckman, 2008). Developmental deficiency in early childhood cannot be easily compensated in later years and its cost is extremely high (World Bank, 2009). Early intervention in early education years can lead a powerful beginning for education as reversing negative cases (Çelenk, 2008; Cetin, Gulhan, \& Katranci, 2018). In a study, Whitehead (2016) states that the children who have attended preschool have better literacy acquisitions than the children who have not. Children who are not sufficiently ready to start primary education are more likely to develop literacy problems (Scarborough, 1998). Acquiring literacy skills in early ages is essential to success in school and in life.

If social environment supports children holistically in terms of cognitive, linguistic, social, and emotional development; children can be successful both in school and life (Grunewald, 2018). For the improvement of literacy skills which are natural processes in the early years of human life, both preschool school teachers and the other adults in inner circle of children are important for children. Children need their teachers' guidance and supports to improve their literacy skills. Quality preschool teachers can provide children with rich learning environments that support their readiness for literacy as a part of school readiness. School readiness provides benefits at intrinsic and instrumental levels (United Nations Children's Fund [UNICEF], 2012). A successful school transition not only instrumentally is 
the safe way of social and economic development of a society, but also intrinsically is the safe way of a good start to school, low dropout rate, higher academic engagement, achievement, graduation, and employment rate for children. In line with this understanding the main purpose of preschool education in Turkey is supporting children to get necessary skills for primary education (Ministry of National Education [MoNE], 2013a), and it is the main responsibility of the preschool teachers.

Literacy preparation (LP) starts in preschool education, and the experiences in these years can form a basis for literacy learning and teaching (Young, 2003). Children in preschool education have their literacy experiences in a developmental order (Pinto, Bigozzi, Gamannossi, \& Vezzani, 2009). Some of skills which children get naturally before starting formal education are based on LP skills. While acquiring these skills, children have an active role. This role is a lifelong process which starts with the birth of children (Johnson, 2015; Zygouris-Coe, 2001). First literacy education is a language acquisition process which starts in early childhood and goes on learning literacy skills in primary education (Baş, 2006). First literacy education consists of basic steps. These steps are LP, feeling the voice, writing the letter, syllable-word-sentence and writing a text. Each step is important for the next steps. LP is the first step in this process and it is a significant starting point like the first button of a shirt. For this reason, it is important that LP in preschool education should be conducted systematically. Preschool education curriculum is one of the instruments to make LP in preschool education systematic.

Turkish preschool education curriculum states that LP in preschool education aims to make children ready for primary education and make their transition to primary school easy, but never aims to teach literacy or writing/reading letters (MoNE, 2013a). In preschool education curriculum it is strictly pointed out that the literacy preparation activities (LPAs) should not be organized as reading, writing or concept studies; however, can be designed as drama, music and game or game-like activities for children. Some examples that are stated for LPAs in preschool education are listed below (MoNE, 2013a, pp. 44-45): 1.Visual perception activities (hand-eye coordination, shape-space distinction, shape stability, position in space, spatial relationships, speed, etc.), 2.Auditory perception/ phonological awareness activities (listening, speaking, voice awareness, distinguishing, creating words as beginning or ending with the same sounds, etc.), 3.Attention and memory activities (finding similarities or differences, keeping memory, remembering, etc.), 4.Basic concept activities (some activities based on concept list in program book and other related/necessary concepts), 5.Problem-solving and guessing activities, 6. Using a pencil and hand-skill activities (using pencil correctly, controlling a pencil and using it correctly, drawing, coloring, cutting, folding, kneading, sticking etc.), 7. Activities on the improvement of self-care skills, 8. Activities on the improvement of self-reliance and independent attitudes, 9. Activities on the improvement of social and emotional maturity, 10. Activities on literacy awareness and motivation improvement, 11. Senses education activities, 12. Breath and rhythm activities etc.

In preschool education, children get some knowledge on phonology, alphabet, writing terms and speaking skills. With the help of first literacy education, children can acquire the verbal codes of their native language and they can combine these codes with visual codes in their mother tongue. The first literacy education can be defined as comprehending 
the content of a written text as knowing the relationship between letters in Turkish alphabet and as understanding the letters of a language in a written text. Naturally, it can be accepted that visual and verbal awareness for written and verbal signs can be two significant parts in the first literacy education (Özcan \& Özcan, 2014). Before learning reading or writing, children learn to understand verbal language and to express themselves in this language. Acquired verbal language, visual-verbal awareness, thinking, cause-effect relationships, ordering, making generalization are the steps of LP and these are developed starting from early childhood education period (Cevher-Kalburan, 2010).

While learning reading skills, children should have visual perception skills in order to understand the letters and words in a written text (Yost \& Jodi, 2001). From the birth of a child, recognizing the written words, billboards or signs and trying to read them are important skills that can be supported by firstly parents and then by preschool teachers. Understanding, defining, and interpreting of visual knowledge is covered in visual perception (Brown, 2008). Realizing visual or written texts, understanding the features of writing, improving observation skills, and seeing to read written texts or to write the reading texts can be helpful for children in their LP process. Children who get these experiences in their preschool education process can easily begin to literacy education process (Bay \& Alisinanoğlu, 2008). Reading stories to children in preschool education can help them to improve their awareness on stories and to comprehend stories in a better way. Reading stories can also help children to learn written language rules and to improve their knowledge on printed materials. Additionally, discussing or brainstorming on the stories can help to be aware of strategies which are used to understand stories in a better way (Sonnenschein \& Munsterman, 2002).

Literacy skills can be acquired with the help of environmental factors very similar to the other skills in other disciplines. These LP skills that are stated as simple or primitive literacy by Üstün (2007) can be naturally improved in a rich and well-designed learning environment. With the help of activities that are used in preschool education, children can improve their literacy skills and be positively motivated on literacy (Wildová \& Kropáčková, 2015). The attitudes of parents and teachers can affect the attitudes of children. Both teachers' understandable, democratic, and positive attitudes and parents' effective communication with their children can positively affect the students' attitudes toward learning the language (Lababidi, 2016). However, it is difficult to say that all parents and preschool teachers know this natural process for children well (Üstün 2007).

It is well known that teacher quality is the most significant school variable that affects children's success (Hattie, 2003). A successful teacher can push lower level children up successful children's level (Ripley, 2010). For LP, preschool education teachers have a vital role (Taşkın, 2014). The success of any kinds of policies in the education system largely depends on the professional perceptions, competencies, and dedication of the practitioners. (McLaughlin, 1987). In this scope, teachers as being the appliers of preschool education curriculum should have enough knowledge and skills on primary school and LP, and they should take into consideration the main aims of LP in preschool education curriculum while designing activities and learning environments on LP for children in their classes (MoNE, 2013b). It is important for a successful beginning that teachers should know the developmental characteristics of the children in their classes and they should design activities to learn literacy appropriate for the 
children having different developmental characteristics and needs. Preschool and primary school first grade teachers -there after stated as primary school teachers- are required not only to have content knowledge but also pedagogical and pedagogical content knowledge. In order to teach in each grade in line with the centrally developed curriculum by MoNE, preschool and primary school teachers should know the basic educational approaches in curriculum and students' characteristics and needs. By this way they can select the teaching methods and materials fitting best to the needs of the students. However, Genç-Ersoy (2021) who examined the studies conducted in Turkey stated that preschool teachers mostly do not have enough knowledge on early literacy, and they generally have some confuses on early literacy and preparation for literacy for their students. Genç-Ersoy also indicated that; preschool teachers should be supported in terms of LP based on current knowledge on the field.

Results of the Program for International Student Assessment (PISA) show that 15-age-year-students in Turkey have lower level scores on reading skills than the average (The Organization for Economic Cooperation and Development [OECD], 2019). Turkey has limited number of students who have high-level of reading skills (Aydın, Erdağ \& Taş, 2011). Additionally, Turkey's preschool education schooling rate is the lowest among OECD countries (OECD, 2017). PISA results show that unlike the other OECD countries, in Turkey taking more years of preschool education do not make higher level of achievement in fifteen years old (MoNE, 2016). 15-age-year-students in Turkey who took two years of preschool education do not have higher achievement level than their peers who took one year of preschool education. This is implying that the practices made after the first year in preschool education turn into a repetition of the first year. PISA results and the results of the studies showing the benefits of preschool education made access to quality preschool education as one of the priorities of policy makers (MoNE, 2018) and educational research community. Preschool teachers have the power to influence early literacy skill development and potentially impact children's later success in school (Dennis \& Horn, 2011, p.30). Additionally, the LP outputs produced by preschool teachers are the inputs for primary school first grade teachers. For that reason, understanding what means the LP for preschool teachers and primary school first grade teachers, how preschool teachers support the literacy development, the problems they experienced and their recommendations for better LP is very important. Knowing the LP studies in preschool education not only led to the development of policies on increasing the quality of preschool education but also the policies on literacy performance in primary education and later.

In line with the key issues mentioned above, the main purpose of this study is to reveal the views and recommendations of the preschool and primary school teachers on the LP studies conducted in preschool education. As for this main purpose, the questions stated below are tried to be answered:

1. What is the meaning of readiness for literacy for preschool and primary school teachers?

2. What are the views of the preschool and primary school teachers on current situation of LP in preschool education?

3. What are the problems preschool and primary school teachers encounter during LPAs?

4. What are the recommendations of preschool and primary school teachers on the LP in preschool education? 


\section{Methodology}

\section{Research Design}

This study is designed as phenomenological research that is one of the qualitative research methods. The purpose is to explain the views, experiences, and perceptions of individuals on the phenomenon (Yıldırım \& Şimşek, 2016) and to describe the cases in which the phenomenon occurs (Creswell, 2013). In the study, the phenomena of the LP in preschool education is examined from the perspective of both preschool teachers and the the first grade teachers.

\section{Participants}

In phenomenological research, individuals who have experiences and easily reflect these experiences on the selected phenomenon are the main data source (Yıldırım \& Şimşek, 2016). On this basis, preschool teachers who have firsthand experiences on the phenomenon of "LP in preschool education" and the first grade teachers who have meet the students graduated from preschools are the participants of the study. While determining teachers in both groups; maximum variation and criterion sampling were conducted (Yıldırım \& Şimşek, 2016). In this scope, while selecting the participants the variables such as the teaching experiences, school type, grade and classroom size is also taken into consideration. In criterion sampling being the first grade teacher during the study is taken as the criteria. Demographic characteristics of the participants are given in Table 1.

As it is seen in Table 1, the participant groups of this study are conducted with totally 21 teachers -12 preschool teachers and 9 primary school teachers- who had been teaching in 2015-2016 academic years in both public ( $\mathrm{f}=17)$ and private schools $(\mathrm{f}=4)$ in a city in western Turkey.

All of the preschool teachers are female who have been teaching for nearly 15 years and many of them have been teaching in public preschools which present part-time education for students and the average class size is 17 students in these preschools. Except for one participant, all primary school teachers are female and many of them have been teaching in public schools in city center for nearly 22 years. Except for one primary school teacher (PT8) who has been teaching in a private school for three years, all of the primary school teachers have experience two or more times for the first grade teaching process. One of the preschool teachers (PT6) was graduated from primary school teaching department and she had been teaching in primary schools for ten years; then she transferred to preschool teaching department as a preschool teacher; and PT6 is a teacher who has experience on LP for both in preschools and primary schools. PT7 is also a teacher who has been teaching as primary school teacher even if she was not graduated from specifically this department. 
Table 1

Demographic Characteristics of the Participants

\begin{tabular}{|c|c|c|c|c|}
\hline & \multicolumn{2}{|c|}{ Preschool Teachers } & \multicolumn{2}{|c|}{ Primary School Teachers } \\
\hline & $\mathrm{f}$ & $\%$ & $\mathrm{f}$ & $\%$ \\
\hline \multicolumn{5}{|l|}{ Gender } \\
\hline Female & 12 & 100.0 & 8 & 88.9 \\
\hline Male & & & 1 & 11.1 \\
\hline Total & 12 & 100.0 & 9 & 100 \\
\hline \multicolumn{5}{|l|}{ School Location } \\
\hline City center & 10 & 83.3 & 7 & 77.8 \\
\hline Village & 2 & 16.7 & 2 & 22.2 \\
\hline Total & $\begin{array}{l}1 \\
2\end{array}$ & 100.0 & 9 & 100.0 \\
\hline \multicolumn{5}{|l|}{ Class Type } \\
\hline Independent preschool & 1 & 8.3 & & \\
\hline Kindergarden in primary school & 10 & 83.3 & & \\
\hline Kindergarden in elementary school & 1 & 8.3 & & \\
\hline Total & $\begin{array}{l}1 \\
2\end{array}$ & 100.0 & & \\
\hline \multicolumn{5}{|l|}{ Teaching Hours } \\
\hline Whole day & 2 & 16.7 & 9 & 100.0 \\
\hline Half day & 10 & 83.3 & & \\
\hline Total & $\begin{array}{l}1 \\
2\end{array}$ & 100.0 & 9 & 100.0 \\
\hline \multicolumn{5}{|l|}{ School Type } \\
\hline Public school & 10 & 83.3 & 7 & 77.8 \\
\hline Private school & 2 & 16.7 & 2 & 22.2 \\
\hline Total & 12 & 100.0 & 9 & 100.0 \\
\hline $\begin{array}{l}\text { Experience } \quad \text { Min: } 2.00, \text { Max:32.0 } \\
\text { (Years) }\end{array}$ & an: 15 & .43 & $\begin{array}{l}\text { Min: } 3.00, \text { Max: } 37.00, \mathrm{M} \\
10.83\end{array}$ & \\
\hline $\begin{array}{ll}\text { Class size } & \text { Min: 13.00, Max: } 23 \\
& 3.38\end{array}$ & Iean: & & Min: 17.00, Max: $27.00,1$ & $=3.28$ \\
\hline
\end{tabular}




\section{Data Collection Procedure}

Interview is a basic data collection tool for phenomenological research. Interviews provide an in-depth presentation of the experiences and meanings of the phenomenon studied, with the various opportunities they offer to the researcher, such as interaction, flexibility, and asking additional questions (Yıldırım \& Şimşek, 2016). In this sense, the data is collected via face-to-face interviews in this study. As for interviews, semi-structured interview forms which are specifically developed by the researchers for both preschool and primary school teachers are used as data collection tool. Draft interview forms are designed as referring the related literature, and as using the knowledge of the first researchers' experiences and observations on preschool education environments within the scope of preschool teaching department programs and the observation and experiences of the second researcher who is an expert on literacy education in primary school. In both interview forms, there are 7 close-ended questions for the demographics of the participants, 11 open-ended questions for the preschool teachers and 5 open-ended questions for primary school teachers on LP in preschool education.

In qualitative research, making strong inferences is possible only with qualified data. Credibility is a strong sign of reliability (Teddlie \& Tshakkori, 2009). In this perspective, the views of one expert in preschool teaching department, one expert in primary school teaching department and one expert in assessment and evaluation department are asked in order to supply internal validity of the interview forms. The interview forms are reformed after getting expert views and the final version of the interview forms are piloted with one primary school teacher and one preschool teacher who are not the participants of this study. Additionally, by collecting data from both participant groups triangulation and participants' confirmation is provided for the reliability of the study.

The data in this study was collected by the researchers via face-to-face interviews conducted in 2015-2016 spring semesters. After getting permission from the participants, the interviews were recorded. Interviews took minimum 25 , maximum 44 and average 30 minutes.

\section{Data Analysis}

The data is analyzed via content analysis in this study. The purpose of content analysis is to classify collected data source (interview records for this study) as combining similar data under the sub-headings of determined concepts and themes, and then make them more understandable (Creswell, 2013). In the first step of content analysis which is completed via Nvivo 11, open-coding and in the second step, axis-coding is used (Gürbüz \& Şahin, 2016). In this process, firstly, determined codes have always been compared with each other, and then more understandable themes have been created as considering the similarities and relationships. In this way, random data is reformed as meaningful themes (Miles \& Huberman, 1994). As referring the research questions, the findings of the study are visualized after getting last version of the themes (Miles \& Huberman, 1994). For internal reliability, the themes are interpreted as considering the relations between the codes below them and when necessary, relations with the codes in other themes. 
Credibility is one of the basic factors to get correct data in qualitative research. One of the ways to increase credibility is coding reliability. For this purpose, some parts of the interview forms are randomly selected, and these are independently coded by the researchers, which led to $89.00 \%$ reliability between coders based on the formula of interrater reliability=100xconsensus/(consensus+dissension). For the different codes, the data is coded again as making a consensus. Additionally, "objective another researcher" is integrated into data analysis procedure, and with the help of the objective researcher, the interpretations of the researchers on the codes are clarified and possible biasness can be seen clearly (Teddlie \& Tashakkori, 2009). For the validity of the study expert's views on the methodology and the inferences made from the findings are taken. For the transferability, all steps of the study are presented transparently (Miles \& Huberman, 1994).

In qualitative research studies, stating finding via quantitative data helps to compare themes and categories (Yıldırım \& Şimşek, 2016). In this sense, the data collected for this study is supported via quantitative data as presenting frequency or percentages; however, the main purpose is not presenting a generalization for the study but just stating a different perspective for the readers. Additionally, direct quotations are presented in order to support the interpretations and to reflect the teachers' views directly. In direct quotations preschool teachers are stated as PST1, .., PST12 and primary school (first grade) teachers are stated as PSFGT1, ..., PSFGT9.

\section{Findings}

To present findings, first, a detailed description was made by presenting the main themes, then the explanations of the subthemes that make up them, and direct quotations to support them were given.

\section{Figure 1}

General Outlook of Preschool Teachers' and Primary School Teachers' Views and Recommendations on LP in Preschool Education
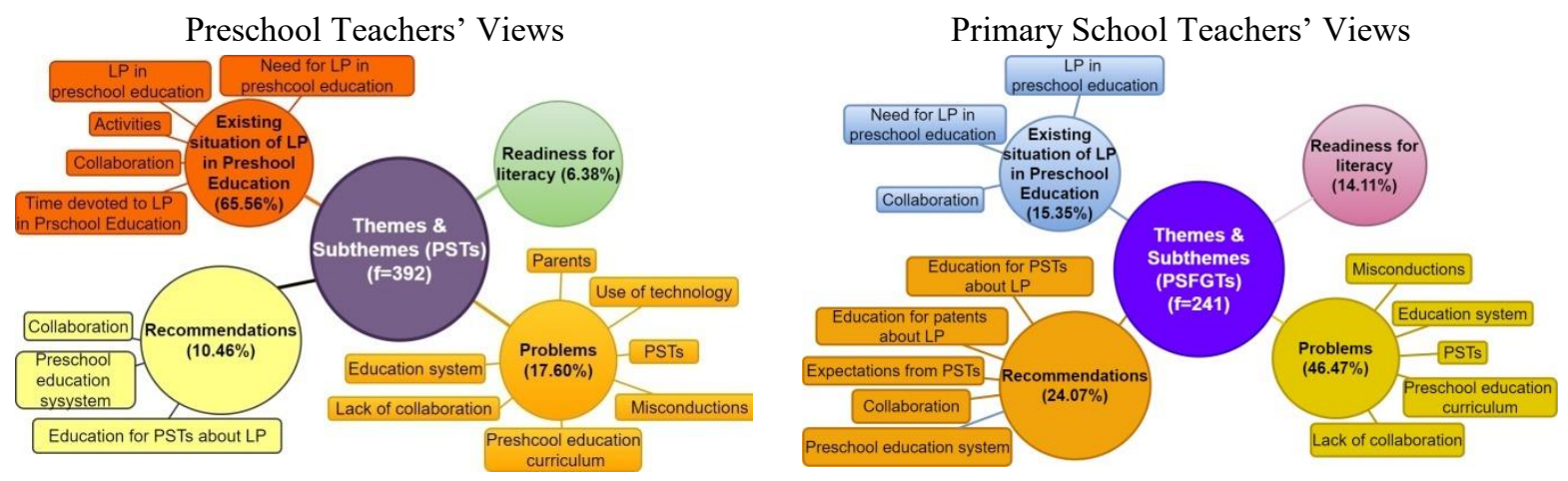

Figure 1 visually summarizes the themes and sub-categories that are found after content analysis on the views of preschool and primary school teachers. There are 392 codes that are collected from the data on preschool teachers' views, and 241 codes from the primary school teachers' views. The codes of both groups are categorized under the four main themes as namely readiness for literacy, existing situation of LP, problems and recommendations. 
Knowing the meaning of "readiness for literacy" for both preschool and primary school teachers helps to understand LPAs in preschool education. The views of both groups on "readiness for literacy" are presented in Figure 2.

\section{Figure 2}

The Views of Preschool and Primary School Teachers on Readiness for Literacy
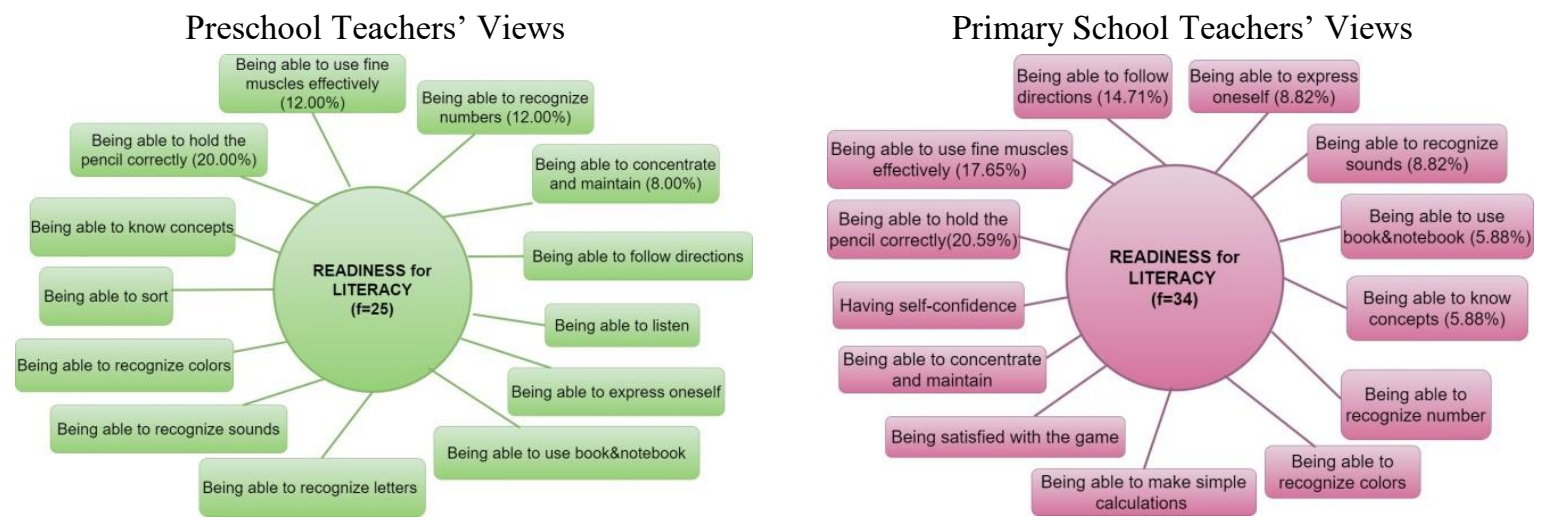

According to Figure 2, views of preschool and primary school teachers on readiness for literacy are collected under 13 parallel themes. The views of preschool teachers are generally seen as directly related concepts to literacy, such as holding pencil correctly, using fine muscles effectively, recognizing voices and letters; and indirectly related concepts such as knowing the numbers, concentrating, expressing oneself and recognizing colors. However, the views of primary school teachers are generally seen as directly related concepts such as holding pencil correctly, using fine muscles effectively, recognizing voices, using notebook/book, knowing the concepts; and indirectly related concepts such as obeying the rules, expressing oneself, having self-confidence and satisfying with the game. For both groups, holding pencil correctly, using fine muscles effectively, knowing the basic concepts, recognizing sounds/numbers/colors, concentrating, and expressing oneself are seen as the common themes; however, different than the preschool teachers, primary school teachers also emphasized social maturity with their opinions gathered under the themes of expressing oneself, self-confidence, being satisfied with games, and obeying the rules.

PSFG2: The student should be able to hold pencil at least, because students should learn to hold pencil in preschool education since they use pencil in these years. The wrong holding pencil starts in preschool education if it is not interested by teachers. And we cannot make it correct.

PSFG6: First, students should learn to hold pencil. Some of students hold it up; some of them hold it down. Secondly, their muscles should be ready to hold pencil, use scissor in preschool years. At least, they can count to 10, [...] they should learn addition and subtraction in mind at least.

PSFG1: Students should learn writing on a notebook as orderly not randomly on study worksheets.

PSFG7: Instead of teaching something, students should learn games. They should come to primary school as satisfying with the games.

PSFG9: I think students should certainly know being in a society when they come to classroom before learning literacy. 


\section{Figure 3}

The Views of Preschool and Primary School Teachers on the Current Situation of LP in Preschool Education
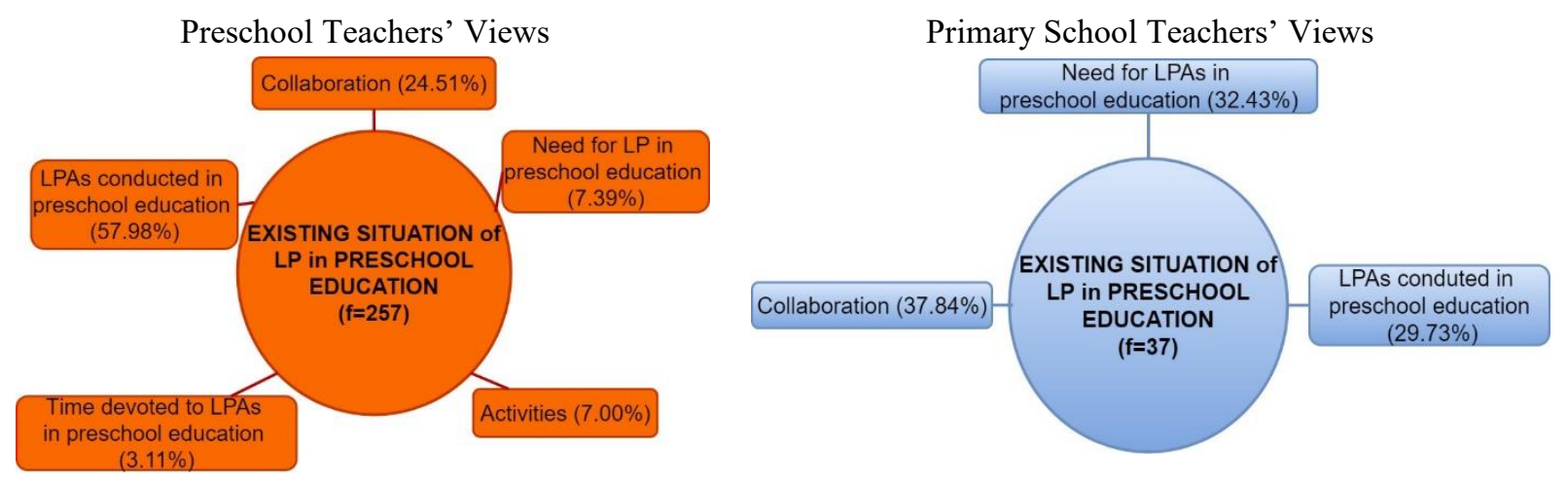

In Figure 3, it is seen that preschool teachers stated much more detailed views on the current situation of LPAs than the primary school teachers did. The necessity of LP in preschool education, LPAs and collaboration are seen as the common themes for both groups of teachers. Preschool teachers additionally state some views on the LPAs and the time/duration of the activities.

In the current situation theme, preschool teachers say that there should certainly be LPAs in preschool education and they do enough activities to make their students ready for literacy. The primary school teachers also state that LPAs should be in preschool education since these have positive effects on students; however, some of them state that this case can lead inequality of opportunities for students who do not have an opportunity of accessing the preschool education, and some others indicates that students do not start primary school as being ready for literacy even if they get a preschool education.

PST10: Of course, LPAs should be done because one of the purposes of preschool education is to make students ready for primary school education.

PST1: I think that we teach holding pencil, new concepts, making relations, ordering, grouping, colors, numbers etc. That is, I think we educate students as 'double-dome' students for primary school education.

PSFGT1: sometimes we see that students did many well activities and many of them were completed thanks to preservice teachers... [...] the activities seem nice but both you and I know that these are not of students.

PSFGT9: I observe students, some of them know double digit numbers, but some of them do not know even 2-3 as numbers. [...] So what? The self-confidence of students... they know but I do not know, students are strangers to school, their teachers and friends are new for them. If some of students do not know the same things, they can be introvert and there is lack of self-confidence and that psychology

PSFGT2: We do not feel that students are ready for writing letters or lines. There are maximum 5-6 students who can be ready for them. You said 'didn't they have any preschool education'? 
PSFGT1: Each student does not have preschool education, however, in primary school education some of students know numbers or letters thanks to preschool education and the others do not know them; it leads inequality of opportunities.

As for LPAs themes, the views of preschool teachers are collected under the main themes namely LP, improving social skills, listening, improving vocabulary knowledge, time for LPAs, preparation for reading and concentration. Some of the preschool teachers state that they think basic mathematics knowledge as a kind of activity for LP.

The preschool teachers mainly state that they do drawing activities, matching, completing dotes, improving finger muscles for LPAs; some of them rarely state that they do some activities on holding pencil correctly, sitting on desks, writing sides and using lines for writing. The preschool teachers, in general, clarify that they do some activities for expressing oneself and speaking after getting permission in classroom in terms of speaking skills preparation activities. Some of them state that they use tongue twisters, songs, poems, and stories to improve speaking skills and vocabulary knowledge. Two preschool teachers stated that they do some extra speaking activities with the handicapped students in their classes. Some of the preschool teachers say they state some rules like giving permission to go out classroom and not having a break before completing tasks, even increasing the duration of the activities in the second semester for their students. A limited number of the preschool teachers say that they use break-time for their students, or they take attendance of students in order to make students ready for the first grade education as socially. The preschool teacher who had been teaching primary school before being a preschool teacher states that she use some activities to conduct reading-writing distance for students.

PST10: For instance, dear instructor, we use a ready plan and the vocabulary items or concepts that will be taught today are written under the plan. We try to teach them as much as possible.

PST3: We use drawing activities as beginning with the easiest one and it goes on harder and harder. Additionally, I use matching, ordering, classification, finding missing points, completing, concepts, and contrasting activities for LP. As for sounds, we teach vowel sounds e, a... especially in the second semester in terms of recognizing the sounds.

PST1: That is, students can hear a different vocabulary item and we teach them within the activities. We use Turkish language activities. We teach them as for LPAs.

PST2: For instance, what can I do, I do punch activities to teach blowing. We play in sand pool too much... Whether it is planned or not, we always play dough to have a break. We do hand exercises.

Although there are huge numbers of views of the preschool teachers on LPAs in preschool education, the limited numbers of views of primary school teachers are categorized under the main themes namely drawing exercises, recognizing numbers and colors, and reading stories. 
PSFGT2: They do drawing activities. Even, they teach letters highly. They teach the numbers that should not be taught. These activities can be useful for some children, but these can blow out reading desires of some children. Why? They give lots of homework. Children burn out due to homework.

As for the activities theme, the preschool teachers state that they use stories, art activities, Turkish language and gamelike activities for the aim of LP. As for time/duration theme, it is seen that the views of the preschool teachers are different from each other. Some of the preschool teachers state that they do LPAs 15-20, 30, 40-50 minutes or an hour in each day; however, some others state that they do these activities three-four times in a week.

As for current situation main theme, there are some views collected under the collaboration subtheme for both groups. The preschool teachers state that they have collaboration with parents, teachers, preschool teachers from other schools, pre-service teachers and guide teachers, but no collaboration with school administrators because they do not need it. $66.66 \%$ of the preschool teachers believe that they need collaborate with primary school teachers; $83.33 \%$ of them think that there is no systematic collaboration, and the content of collaboration is so limited. The preschool teachers who have been teaching in public schools state that collaboration with primary school teachers is generally limited to visit their old students in the first grade and to give information about their old students if it is required, to get professional feedback from primary school teachers in informal places, and to rarely share sources with primary school teachers. Apart from public schools, two of the preschool teachers teaching in private schools state that preschoolers and the first grade students do some reading activities together, and one of these teachers says that the primary school teacher in their school comes to her class and make some LPAs with preschoolers in her leisure time.

PST10: Collaboration is needed because correcting wrong knowledge takes one year for children in terms of first grade teachers, for this reason, there should be collaboration.

PST3: There is no collaboration. That is, they get general knowledge as talking with as if we have a well communication with each other because in general many teachers in crowded schools cannot see each other.

PST1: We sometimes visit our teachers in order to meet them at the beginning of the semester. They say "there is your teacher, new students etc.", it is not so systematic.

More than half of the preschool teachers state that they collaborate with other preschool teachers mainly to make plan, determine activities, give homework or share materials.

PST1: There are three teachers in our group, and we collaborate with each issue, we do common activities. While making plan, implementing it [...]. We share materials. We conduct our activities in a coordinated way.

Some of the preschool teachers state that they also collaborate with pre-service teachers; some others state that they collaborate with other preschool teachers from different schools, and the others say that they can collaborate with parents. Many of the preschool teachers define parent-collaboration as helping their children's homework at home; 
some of the teachers define this collaboration as reading stories in class for students; and the limited number of them define it as reading book at home for their children or doing LPAs.

PST4: I have a group with my classmates from university. I meet them. I am a member of some websites for preschool teacher.

PST3: I suggest it at home certainly for parents, they can buy play dough, they can give permission to play games and they can do exercises with pencil at home. My students, absolutely, go to home with their homework for each Friday [...] It is just one page, and it is generally about drawing, numbers or concepts based on LP.

PST10: Every day (in classroom), I want to say we read book, but unfortunately, I cannot read. We somehow give this responsibility to parent.

Additionally, in collaboration subtheme, $44.44 \%$ of the primary school teachers believe that collaboration is needed; however, $77.78 \%$ of them state that there is no collaboration. The limited numbers of the primary school teachers who say they collaborate define this terms as getting information on some students, examining preschool education sources, visiting kindergarten classrooms and doing LPAs in kindergartens.

PSFGT3: Last year, for instance, I visited two different classrooms, I examined their activities. They do lots of coloring activities and hand exercises [...] but according to me, students should obey the classroom rules, or they can just listen to my instructions, it is enough for me.

PSFGT8: I let them play with play-dough to improve their fine muscles, we listened to music together, and I joined dancing courses. I think there should be friendship between students and teacher. I tried to do it.

In Figure 4, it is seen that the primary school teachers state much more problems on LPAs in preschool education. The views of both groups on the problems collected under the similar subthemes even if the percentage of them is different. The views of both groups of teachers are collected under the subtheme of collaboration. Many of the preschool and primary school teachers state that there is no systematic collaboration between preschool teachers and primary school teachers in terms of LPAs. According to the participant teachers, teachers in both groups do not know each other and it is the basic reason of lack of collaboration; that is, preschool teachers and primary school teachers do not generally visit their classrooms, they also do not know the other groups' curriculum. According to some preschool teachers, some of primary school teachers are reluctant for collaboration. On the other hand, some primary school teachers stated that they ask their requests in informal places and worry about if I request something or if I can be misunderstood.

PSFGT2: We cannot join the courses, of course. We have also lessons, and they also have. We cannot disturb them, and we also don't have enough time. Sometimes, we can talk during meetings randomly. 
PS6 (old primary school teacher): Since there is no break-time in preschool education, preschool teachers are generally disconnected. They mainly come together in general meetings, if there is no personal communication, there is no collaboration.

PSFGT1: If I say I go to their classroom, it will be lie, we are also busy. We can see them rarely during some organizations. We sometimes say this need, but it is not based on our saying, there should be [...] a program because when we say this need, it can be personalized, our colleagues can misunderstand it.

\section{Figure 4}

The Views of Preschool and Primary School Teachers on the Problems for LP in Preschool Education

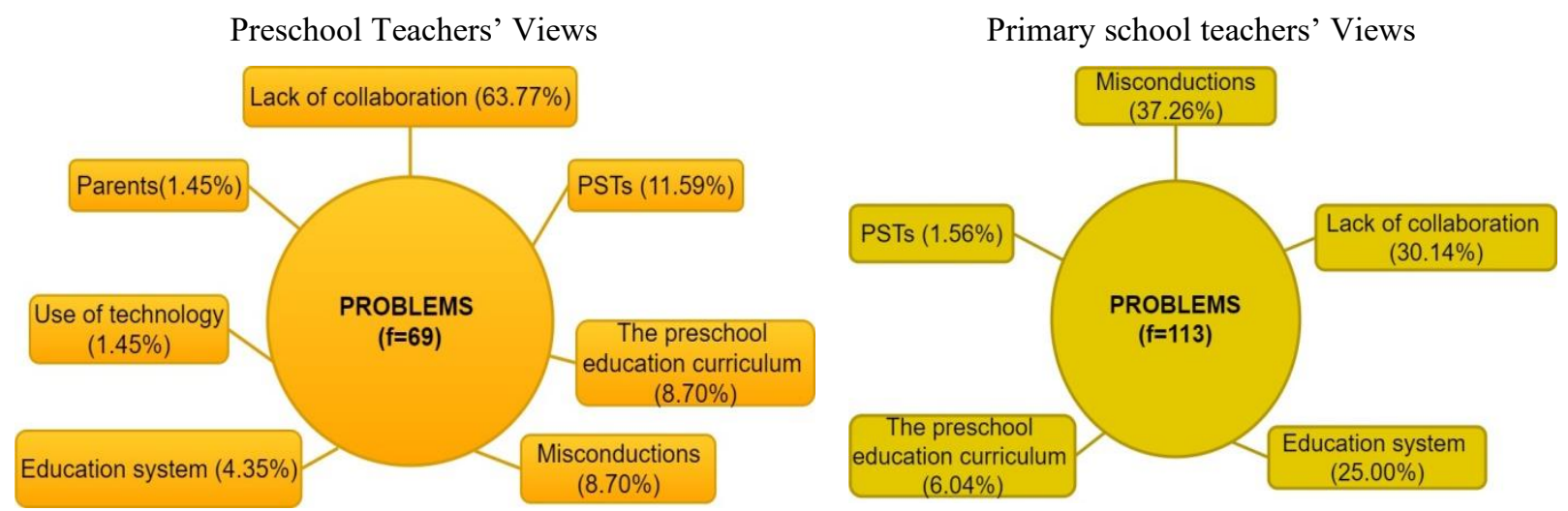

The views of the preschool teachers on the problems are collected in the subtheme namely education system. The lack of a formal collaboration program, the problems on working hours, not compulsory education for preschools, lack of break-times in preschools and not reaching preschool education programs to primary school teachers are the common problems based on the education system for both groups of teachers. Additionally, according to some preschool teachers, changing primary school teachers for every year and classrooms which are different from the primary school classrooms are the problems related to the education system. According to some primary school teachers, also, different classroom environments and flexible classroom rules in preschool education can be some education system problems that negatively affect LPAs in preschool education.

PST1: Since students can do whatever or whenever they want in preschool, they struggle in the first grade.

PST3: There is no common work. There are development reports. Many of these reports cannot reach to primary school teachers.

PST8 (teacher in middle school kindergarten): Being in a middle school building is disadvantageous for us because I gave all folders on my students to their primary school teachers in previous years, but now I even don't know their new teachers.

According to both preschool and primary school teachers, some of the problems based on the LPAs are based on misconducts in preschool education. According to some preschool teachers, the use of worksheets instead of 
notebooks and ignorance of LPAs are the examples of misconducts; however, according to some primary school teachers, teaching to write numbers and letters incorrectly, not teaching to hold pencil, using worksheets instead of notebooks, doing too much coloring activities, having visual worries about art activities, teaching only vowels, not following up students during LPAs, stating different LPAs by different teachers and beginning primary school as reluctantly because of these problems are the misconducts in preschool education.

PST10: We just teach vocabulary items that start with vowels, not others.

PST1: I think there should not be reading, writing, sound repeating or teaching literacy activities that are done some of our colleagues. Because of these activities, it is thought that they do the correct one and we do not teach enough concepts to our students.

PST8: There are some colleagues who teach letters as beginning with the first one or using writing notebooks, but I don't agree with them. Why? [...] Our mistakes are not tolerated.

PSFGT2: They do drawing activities. Even they teach letters too much. Even they teach the numbers which should not be taught for this level. They give lots of homework. Children are disgusted with them.

PSFGT1: I cannot say anything for concepts but when we begin to write, there are some students in my classroom who hold the pencil at top.

PSFGT3: There is photocopy, now [...], we print worksheets from internet, children draw on lines [...]. Indeed, using notebooks are more effective than using ready materials.

In the main theme of problems, some parts of the teachers' views are collected under the subtheme namely preschool education program. Insufficient preschool education program in terms of LPAs and being not coordinated with primary school education program can be seen as the common problems of the participant teachers in both groups as for preschool education program. Additionally, for some preschool teachers, lack of criteria on literacy readiness and the use of ready published sources instead of the curriculum are the other problems on preschool education program.

PSFGT9: Each one of preschool teacher use program differently, indeed. I wish there was a common application, in this case, there will be a program, plan or guidebook, and all of us will be in the same level, and the chaos in the first grade and different levels will be disappeared.

PST1: There is no clear criterion. We reach the goals as using our own criterion, experiences, or learning, but there certainly should be a criterion.

Another subtheme for problems is teacher subtheme. More than half of the preschool teachers state that they do not have enough knowledge on LPAs; some of the primary school teachers, also, think that preschool teachers are insufficient to observe or recognize students.

PST1: We do not have basic information on LP education and as you know, correcting mistakes is more difficult than teaching it for the first time. 
PST9: I did not get any courses at university on this concept, but it was stated in my sources; sitting correctly, looking at books, holding pencil. They were presented as pictures. We presented them as using these pictures for children during the activities.

Apart from primary school teachers, the preschool teachers also think that the use of technological tools like smart boards in preschool education and not presented LP materials by parents can negatively affect LPAs.

PST7: Many of preschool teachers have used smart boards or projectors nowadays [...], they use projectors to read stories, children just watch it. Then they draw pictures, let's say goodbye, then. That is, teachers do not read stories now; we have some friends like that.

PST2: Since I have been teaching in a village, some of students do not have any pencil at home, for instance. We suffer from this case.

\section{Figure 5}

The Recommendations of Preschool and Primary School Teachers on LP in Preschool Education

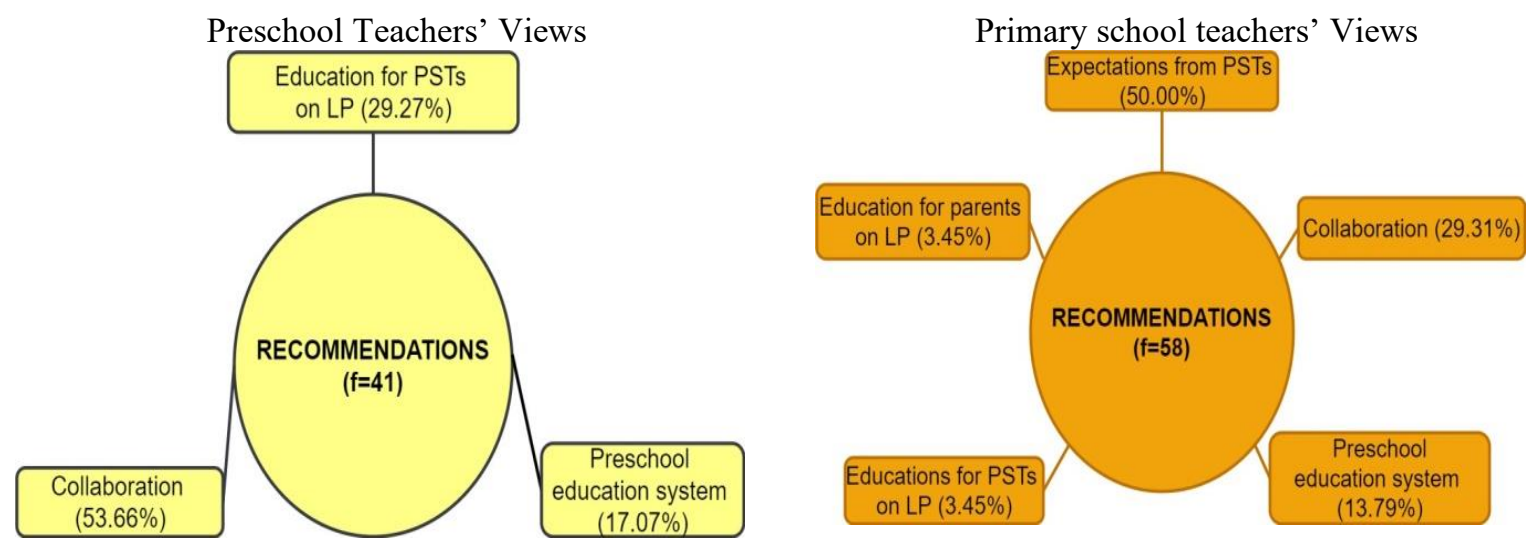

In Figure 5, similar to the theme of problems, the preschool teachers state much more recommendations for the LP than the primary school teachers do. Even if they are different percentages; collaboration, preschool education system and LP education are determined as the same categories for both groups. Different from preschool teachers, the half of the recommendations of the primary school teachers is collected under the subtheme of expectations from the preschool teachers. In this subtheme, the primary school teachers expect from preschool teachers that preschoolers should learn classroom rules- especially in the second semester-, preschool teachers should teach the use of literacy tools such as pencil, notebook, and book; they should also teach to improve fine hand muscles and do game-based LPAs in order not to disgust preschoolers. Preschool teachers should follow up the LPAs in terms of holding pencil etc., improve the creativity of students and encourage students to love their primary school teachers. However, it is not expected preschool teachers that should not teach to write numbers and letters to their students in preschool. 
PSFGT1: A child, firstly, comes to class and s/he does not know the rules, it is OK; but then in April, May or June, there can be some rules because children are unprincipled. That is, they know the concepts very well, but they say 'no, I don't sit' or 'I want to draw picture' because they did it in preschool.

PSFGT6: Firstly, a child should learn holding the pencil, it is very important. Some of them hold it at the top; some of them hold it too down. Secondly, their muscles should be ready to hold a pencil or to use a scissors, their muscles should be strengthened.

PSFGT2: One of my expectations is improving fine hand muscles, and the other is improving the creativity.

As for the subtheme namely LPAs for parents, some of the primary school teachers think that parents should be informed about helping their children for their homework which is based LPAs.

PSFGT8: Their parents should be informed in this sense. This is my expectation from preschool education. Parents should know the cases correctly. They should not encourage their children for competition, and they should not expect anything that is upper children's level.

PSFGT1: When children go to home with homework, their parents should be informed on this case because there is no information for parents.

One of the common subthemes for both groups is collaborations. The participants in both groups think that there should be a systematic collaboration between preschool and primary school teachers. In this sense, they suggest that collaboration should be obligatory, and the tasks of both groups of teachers should be stated as formally. Collaboration should continue throughout the school year so that teachers can make plans together and visit their classrooms throughout the year. Some of the teachers in both groups think that primary school teachers should visit preschoolers in their leisure times. Some of the teachers think professional development weeks, known as seminar weeks in Turkish education system, are the most suitable time to plan and improve collaboration activities.

PSFGT5: The collaboration is limited, but actually it is needed. I have not thought it until now.

PSFGT1: We have stated collaboration for several times, but it is not based on our statements. There should be a formal program.

PSFGT2: I want teachers to visit each other's classrooms regularly and in a coordinated way.

PSFGT3: The primary school teachers who will teach in the first grade can communicate with preschool teachers.

They can do their plans together in seminar weeks and they may go on like that.

Another common subtheme is preschool education system. The preschool teachers suggest for this subtheme that there should be criterion for LPAs in preschool education, students' developmental observation records should be given to primary school teachers and there should be break-time for preschoolers; however, some of the primary school teachers suggest that preschool education should be obligatory and there should be break-time in preschool education system. 
PST6 (Old primary school teachers): If preschool education is obligatory, students will be more successful. It increases the quality of education.

PSFGT6: If developmental observation forms are given to primary school teachers, it will be so good. If it is obligatory, it will be better.

The last subtheme of the suggestions in both groups is the subtheme namely teacher. As referring the findings in Figure 5, preschool teachers do not have enough education or information for LP. Both groups of teachers recommend that there should be LP education in pre-service and in-service teacher training programs.

PST8: There can be a limited training on LPAs for us. I think the system in the curriculum is enough. I think we should mind primary school teachers' business and it should be stated for us in some ways.

PST 10: I didn't get any training on teaching how does a pencil hold, I learn it via my own experiences. I wish I had it at university.

\section{Discussion and Conclusion}

The data on LPAs is collected from primary school teachers and preschool teachers. The answers of the teachers are analyzed via content analysis method. As a result of the analysis, 392 codes based on the preschool teachers' views and 241 codes based on the primary school teachers' views are collected as 4 main themes.

In the main theme namely readiness for literacy, the views of the primary school teachers and the preschool teachers on the term of LPAs are collected under 13 main themes. Some of these views are directly related with the term of literacy readiness, some of them are also related with readiness for primary school. The directly related views of the preschool teachers are collected under the some-themes of holding a pencil, using fine muscles, recognizing letters and sounds. Dönmezler (2016) stated that preschool teachers have done some activities such as drawing, holding a pencil etc. in terms of LP. In their study, Taşkın, Katranc1, and Uygun (2014) found that preschool teachers mostly do drawing, concept teaching and sound activities and they rarely do letter activities as for LP. Akbaba-Altun-, ÇetinŞimşek and Bay (2014) indicated that the teachers generally do concept, sound and drawing activities in terms of LP. Gunn, Simmons and Kameenui (2012) state that preschool teachers should teach the relationship between written and verbal language, and they should teach the relationship between letters, sounds and words in terms of LPAs for children. It is seen that the findings of this study on recognizing sounds/letters and the findings of the related studies in literature are supported with each other. In early childhood, children can understand the relationship between verbal and written language better when they communicate as modeling language functions. When the other related studies in literature are examined, the findings of the study conducted by Dankert, Davies and Gavin (2003) on the effectiveness of doing fine muscles and hand-eye coordination activities to improve writing skills of preschoolers can support the findings of this study. 
Besides, in addition to the views on literacy readiness, the preschool teachers state some views on the readiness for primary school. The subthemes of views are recognizing numbers, concentration, expressing oneself and recognizing colors. This finding shows that preschool teachers are confused on the LPAs and primary school readiness. These subthemes are actually mentioned as the skills acquired in preschool education in Preschool Education Curriculum (MoNE, 2013a). The confusion of preschool teachers on early literacy skills (Genç-Ersoy, 2021) and the definition of LPAs as teaching literacy (Altun \& Tantekin-Erden, 2016; Ergül et al., 2014) are some issues which are stated by the other related studies.

As for the main theme namely readiness for literacy, the views of the primary school teachers are also examined as 13 subthemes. Some of these subthemes are directly related with readiness for literacy, and some others are indirectly related with this term. The directly related subthemes of the primary school teachers are holding a pencil, the effective use of fine muscles, recognizing sounds, the use of notebook and knowing the concepts; however, obeying the rules and instructions, expressing one-self, having self-confidence, satisfying with games are the indirectly related subthemes for this term. It is seen that the indirectly related subthemes are some skills which makes first literacy and learning some rules in primary school easy for students. Bodrova and Leong (2007) stated that giving a chance for learning and creating suitable environment is important and necessary for children. Teachers should enrich their roles as guiding and directing learning process. Preschool teachers should create environment for improving LP skills of students.

For both groups of teachers, the common subthemes on readiness for literacy are determined as holding a pencil, the effective use of fine muscles, knowing the concepts, recognizing sounds/numbers/colors, concentration and expressing oneself. The primary school teachers state the importance of social maturity for children as saying different views which are collected as the subthemes namely the use of book, having self-confidence, satisfying with games and obeying rules. That is, it is possible to say that social maturity is an important component of readiness for literacy.

In the main theme namely current situation, 257 codes constitute 5 subthemes. The first subtheme is the necessity of LPAs. The preschool teachers state that there should certainly be LPAs in preschool education and they spent enough time for children. However, the primary school teachers state that they believe the necessity of LPAs, but there some students who are not ready for literacy education even if they got preschool education. There are some studies in the related literature which support this view of primary school teachers. Erdoğan, Özen, Altınkaynak and Erdoğan (2013) stated that preschool teachers do not focus on LPAs adequately or they do not have enough knowledge on LP skills. It is thought that not having enough knowledge can be based on not having necessary pre-training on this term because Özdemir and Bayraktar (2015) state that less than half of the pre-service teachers cannot define early literacy and they know a few early literacy skills. Moreover, limited number of them knows the positive relationship between early literacy and literacy, but cannot explain the reason of this relationship. 
In the subtheme namely LPAs, the views of the preschool teachers are grouped as writing/speaking/reading preparation, improving social skills, improving listening and vocabulary knowledge, concentration activities and basic mathematical operation. The preschool teachers state that they do some activities such as drawing, matching, completing dots, finger exercises for the aim of improving writing skills preparation; additionally, some of them state that they do some extra activities such as holding a pencil, sitting on desk, writing directions and the use of lines for writing skills. In the studies of Taşkın, Katrancı, and Uygun (2014) and Akbaba-Altun, Çetin-Şimşek, and Bay (2014), it is seen that preschool teachers do some activities such as holding a pencil, teaching concepts and sounds and drawing activities in preschool education. As referring both the related studies in literature and the findings of this study, it is seen that preschool teachers focus on drawing for LP. As for speaking skills, it is seen that many of the preschool teachers do some activities based on expressing oneself and talking after getting permission; some of them do some reading poem, tongue twisters, stories activities in order to improve vocabulary knowledge of students; and some of them state the importance of listening as doing language and storytelling activities. Children can understand the relationship between verbal and written language better when they communicate as modeling language functions in preschool education (Gunn, Simmos, \& Kameenui, 2012). Additionally, getting the first academic education in terms of language skills of 3-6-year-child is one of the important features of this period. Since the basic knowledge on four basic language skills- speaking, listening, reading and writing- in Turkish language is acquired in preschool education period, preschool teachers should be knowledgeable in terms of acquiring four basic language skills. For this reason, it is important that initial preschool teacher education departments should provide pre-service teachers' opportunities for learning LP (Karagöl, 2018).

The preschool teachers state that they do some activities to make their students ready for primary school education except for LPAs. They state that there are some activities such as talking or leaving out the classroom after getting permission, having break-time or checking attendance of students in classroom, and they do these practices in order to make their students ready for the first grade in terms of social skills.

In the subtheme namely LPAs, it is seen that the preschool teachers do some activities such as storytelling, LP, art, Turkish language and game-like activities for the aim of making their students ready to literacy in primary education. These kinds of activities help students to recognize sounds in preschool education. The studies on LPAs show that activities for recognizing sounds are really important for students in order to get literacy skills in their early years in primary education (Anthony \& Francis, 2005; Burgess, 2002; Erdoğan, 2012; Pullen \& Justice, 2003).

The views of the preschool teachers on the time devoted to LPAs are different from each other. Some of the preschool teachers state that they do activities in 15-20 minutes for each day; some others say that they do LPAs 3-4 times in a week. As referring this finding, it can be said that the time for LPAs is different for each one of teachers and there should be a systematic system in order to prevent inequality of opportunities for students. 
The other subtheme of current situation is collaboration is seen as the preschool teachers' collaboration with primary school teachers, parents, the other teachers in different schools, their colleagues, pre-service teachers in faculty of education and guide teachers in their school. One of the preschool teachers who has been teaching in a private school states that the first grade teachers in their school sometimes visits preschool classroom and she do some meeting, adaptation and LPAs with preschoolers in her leisure times in the school. It is thought that these kinds of activities can be a good model for public schools.

As for the current situation main theme, there are 37 codes for the views of the primary school teachers and these codes are collected as 3 subthemes. It can be seen as a natural result that primary school teachers state less views on LPAs in preschool education than the preschool teachers, but it can be also interpreted that primary school teachers do not have enough knowledge on LPAs in preschool education. This finding supports the finding on the problem based on lack of collaboration between two groups of teachers. In the theme namely LPAs, the primary school teachers state that LPAs have positive effects for primary school education; for this reason, these are necessary. However, they state that this can also lead inequality of opportunities for students who do not have preschool education. Some of the primary school teachers think that students are not ready for literacy education in primary school after getting preschool education.

In the main theme namely current situation, the primary school teachers have also some views on collaboration like the preschool teachers. The primary school teachers think that there should be a systematic collaboration between the two groups of teachers, but they say that there is no collaboration. The views of the primary school teachers on collaboration are getting information on some students, examining preschool education sources, visiting preschool classrooms. One of the primary school teachers teaching in a private school states that she does some LPAs with preschoolers. It is seen that preschool teachers have much more and detailed views on current situation of LP but collaboration and the necessity of LPAs are the common themes the two groups of teachers.

In the main theme namely the problems on LPAs, there are 69 codes for the views of the preschool teachers and 112 codes for the views of the primary school teachers. It is an attention-getting finding that the primary school teachers have more views than the preschool teachers. There are five subthemes for the problems in terms of the preschool teachers' views on this theme. As for these subthemes, the preschool teachers, firstly, state that there is no collaboration with primary school teachers and they behave differently from each other. In the theme of the education system, they say that there is no any formal collaboration program designed by MoNE, the first grade teachers change in every year and some of the nursery classes are not in primary schools but in middle schools, so these effects the collaboration among the preschool and primary school teachers negatively. Another problem is about the misconducts in preschool education. The preschool teachers state that using worksheets instead of notebooks and ignoring LPAs can be some factors that affect LPAs negatively in preschool education. There are some problems based on the Preschool Education Programs. Some of these problems are lack of LPAs in the program and the lack of continuity and complementarity with the first grade teaching program. Some of the views on the problems of the preschool 
teachers are related to the teachers. The preschool teachers think that they do not have enough knowledge about the LPAs because of initial preschool teacher education programs poor of LP. In a study conducted by Altun \& TantekinErden (2016), it is seen that pre-service teachers do not have enough knowledge about early literacy. Another problem based on teachers is lack of common sources for LPAs in preschool education; for this reason, LPAs are seen as different from teacher to teacher in preschool education. In a study Dönmezler (2016) examined the suggestions of preschool teachers on LP process and she stated that preschool teachers needed to get sources for LPAs. In another study completed with the primary school teachers, it is seen that a common source book in early literacy education makes the process easier for teachers and it helps common implementations (Aktürk \& Mentiş-Taş, 2011). It is thought that a common source book makes the use of LPAs easier in preschool education and it can be a part of solutions for the problems based on teachers. Additionally, the preschool teachers think that the use of technological tools such as smart-boards and lack of LP books which cannot be bought by parents can negatively affect LPAs.

As for the theme of problems, 112 codes derived from the views of the primary school teachers constitute five subthemes. According to the primary school teachers, also, collaboration is one of the most important problems. As for the subtheme namely education system, the primary school teacher thinks that different systems in preschool and primary school, different classroom environments and flexible rules in preschool education are the problems based on the education system that negatively affect the LPAs.

According to the primary school teachers, some of the problems are related to some misconducts in preschool education. Many of the primary school teachers state that teaching to write letters and numbers wrongly, not teaching to hold the pencil in correct way, using worksheets instead of notebooks, doing too much coloring and drawing, having visual worries about art \& craft activities, teaching just vowels, not following up children during LPAs and differences among teachers on LPAs are the problems for the literacy education in the first grade. Even if there are some acquisitions on recognizing sounds in preschool education curriculum (MoNE, 2013a), preschool teachers just focus on vowels, and it shows that preschool teachers need guidance on LPAs in order to understand the aims of these activities. In a study which focuses on 20 first grade teachers' problems on early literacy education, Başar and TanışGürbüz (2020) stated that one of the problems in preparation activities is holding the pencil wrongly for students. Başar, Doğan, and Üstündağ (2020) observed in their study that preschoolers, firstly, hold their pencil in a wrong way, and after getting information and training supplied by the researchers, they begin to hold their pencil correctly. Improving the skills based on holding a pencil is important and this training should be presented by experts. Children who learn correctly hold their pencils will not struggle when they begin to primary school education. For this reason, it is necessity that the activities for holding pencil correctly should be more systematic for preschoolers. In a study conducted by Şahin, Sak, and Tuncer (2013), preschool teachers pointed that there should not be any literacy teaching in preschool education because teaching literacy in preschool education may negatively affect learning and teaching literacy in primary school. According to the some primary school teachers, doing too much and difficult activities for LP can cause underestimate of the school or unwillingness for literacy in the first grade (Yapıc1 \& Ulu, 2010). In their study based on the early literacy problems of primary school teachers, Başar and Tanış-Gürbüz (2020) state that one 
of the problems on literacy education is based on the activities completed in preschool education. These activities can cause getting bored in first grade and not easily adapted for the classroom. Eminoğlu and Tanrikulu (2018) indicate that children who have learned literacy before beginning to primary school have high level of self-confidence, but they also get easily bored during courses. In addition, Başar (2013) states that in preschool education children may learn literacy skills in wrong way and that creates difficulties for children in learning literacy and for teachers to teach literacy in first grade. Main idea behind this statement is initial preschool teacher education programs do not cover literacy teaching in Turkey. Preschool teachers can do some LPAs, but early literacy education is the profession of primary school teachers. Teachers who will present this education should be trained on this field and they should also be qualified in terms of early literacy education. Otherwise, they may teach literacy in a wrong way that is very difficult to make correct.

In the subtheme namely teacher, the primary school teachers think that preschool teachers do not have enough knowledge on following up students and recognizing them, also; they are incapable of recognizing successful and problematic sides of LPAs. According to Morrow (2001), presenting enriched classroom environments in terms of written materials makes students more motivated for literacy but it depends on teachers' capacity.

When the problems on LPAs in preschool education are examined, it is seen that both the primary school teachers and the preschool teachers mainly state the collaboration as a problem. According to all participant teachers, the reason of collaboration problem is not meeting with each other. It is possible to say that teachers do not know each other personally and also, they do not know anything about other groups' classroom environment and teaching programs. The common problem of both preschool teachers and primary school teachers is collected as the subtheme namely education system. As for this subtheme, lack of formal collaboration program, not having suitable working hours, no obligation in preschool education, no break-time in preschool education and not conveying students' development observation folders to upper grades are determined as the common problems in both groups in terms of education system. For both groups, preschool education program is another common problem. For both groups of participants, the teachers think that preschool education program is incapable of LPAs and preschool education program does not support the first grade teaching program.

As for the main theme namely the suggestions on LPAs in preschool education, the preschool teachers have fewer views than the primary school teachers; however, the common suggestions are teacher training for preschool teachers in terms of LPAs, preschool education system and collaboration for both groups. For preschool education system, the preschool teachers suggest that there should be criterion on LPAs, students' development observation folders should be given to primary school teachers and there should be break-time in preschool education. MoNE (2013a) defines the activities for LP in preschool education program; yet, the skills of a child who is ready for literacy are not defined in the program. For this reason, readiness for literacy cannot be defined by teachers correctly in terms of students' abilities. Therefore, it is needed that preschool education program should be revised as a guide for preschool teachers 
via adding literacy readiness criterion for preschool teachers. The preschool teachers suggest that there should be preservice and in-service training programs for LPAs and skills as a solution for the problem on lack of training.

The suggestions for LPAs in preschool education are categorized under five subthemes. In the expectation subtheme, the preschool teachers are expected to teach classroom rules - especially in the second semester-, to teach the use of some literacy tools such as pencil, notebook and book, to improve fine hand muscles for children, to teach game-based activities for LPAs, not to make students bored, to follow up students in terms of holding pencil etc., to improve creativity and to let their students love the first grade teachers; but they are not expected to teach writing the letters and the numbers in preschool education. As the base of literacy skills, there are some skills such as attention, perception, memory, thinking, contraction, ordering, problem-solving, discussing, matching, grouping, comprehending, communicating, and holding pencil and hand-eye coordination. These skills supply children's development during process (Albrecht \& Miller, 2004). Preschool teachers should design activities, which help improving LP skills, and they should create necessary environments for their students (Bodrova \& Leong, 2007). It is important that children, firstly, understand the necessity of literacy and the relationship between literacy and real life. So, children's positive attitudes towards literacy and school will be supported. Creating awareness and motivation for literacy is really important for reaching the aims of literacy activities. In their studies based on the expectations of primary school teachers from preschool teachers, Tantekin-Erden and Altun (2014) state that the primary school teachers except to get standardized LPAs. That is, they point that all preschool teachers teach similar skills in terms of a standardized program for children. As it is stated above, this case is possible only when preschool education curriculum is revised in terms of expectations and when teachers have a common understanding of the curriculum.

In the subtheme namely parents' training on LPAs, some of the primary school teachers suggested that parents should be informed about how they can help their children for LP based homework at home. However, early literacy is a process which requires professionalism. Correcting an error is too late if it is taught in a wrong way.

The primary school teachers suggest for the subtheme namely preschool education system that preschool education should be obligatory and there should be break-time in preschool education. The primary school teachers, also, suggest for the subtheme namely readiness for literacy that there should be teachers training on LPAs for preschool teachers. Primary school teachers get a course namely "early literacy" in their university years, and they can teach early literacy thanks to this course. Sever (2004) states that literacy education should be presented by qualified teachers. Similarly, in order to teach LP in preschool education system by qualified preschool teachers, it can be proposed that the course "School Adaptation and Early Literacy Education" which was integrated into 2018 preschool teacher training program (Higher Education Council [HEC], 2018) should be a part of new programs in faculties of education after the decision of HEC (2020) to delegate the authority of developing and updating initial teacher education programs to the teacher education institutions in 2020. It is also taken into consideration that the revision of initial preschool teacher education program is one of the main human sources policies of MoNE's Education Vision 2023. 
It is seen that the participant teachers' common recommendation on LP in preschool education is collaboration. Collaboration between preschool and primary school teachers can positively affect readiness for literacy. They are commended that collaboration should be defined as a formal program which goes on throughout year. Collaboration of preschool and primary school teachers help to make plans in terms of students' levels. Both the quality of preschool and primary school can be increased, and it helps students' high benefits.

\section{Conclusion}

The findings of the study show that preschool teachers have some confusion on literacy preparation and readiness. Preschool and primary school teachers are of the same opinion about the need for LP in preschool education on the other hand they have different views about the literacy preparation practices conducted in preschool education. While preschool teachers think that they get preschoolers ready for literacy, primary school teachers think that first graders in their classes do not come literately ready from preschool education. Teachers participated in the study, think that the lack of collaboration among preschool and primary school teachers, some deficiencies in preschool education curriculum and in the education system, and the preschool teachers' imperfect knowledge in the literacy readiness are the possible reasons of inadequacy of readiness of literacy in preschool education. Preschool and primary school teachers recommend systematic collaboration among teachers, review of preschool education curriculum and providing professional support for preschool teachers in terms of literacy preparation and readiness.

\section{Implications}

Preschool education should be obligatory at least for five-year-old children as referring the MoNE (2018) Education Vision 2023. Thanks to this obligation, all of the children can begin to primary school education with a strong foundation. Additionally, preschool education curriculum should be revised as consisting of criteria for literacy readiness and supporting the first grade teaching program holistically. Related to teacher dimension, initial preschool teacher education program should be enriched in terms of LP. Especially in the new process in which faculties of education will design their own programs, it will be useful that there should be a practice course on LPAs for preschool teachers. At system level, there should be formal collaboration program on LP for preschool and primary school teachers.

\section{Limitations and Future Directions}

It can be suggested for other researchers that this study, which is limited with 21 teachers, can be conducted with larger groups of participants and different methods of research.

\section{Acknowledgments}

Preliminary results of this study were presented in the $15^{\text {th }}$ International Primary Teacher Education Symposium, held in Muğla, Turkey, between 11-14 May 2016. 


\section{References}

Akbaba-Altun, S., Çetin-Şimşek, Ö. \& Bay, D. N. (2014). Okuma yazmaya hazırlık çalışmalarına yönelik öğretmen görüşleri [Teacher views on reading and writing preparation studies]. Uşak Üniversitesi Sosyal Bilimler Dergisi, 7(1), 244-263. Retrieved from https://dergipark.org.tr/en/download/article-file/202229

Aktürk, Y., \& Mentiş-Taş, A. (2011). İlkokuma yazma öğretiminde ses temelli cümle yönteminin uygulanmasına ilişkin öğretmen görüşleri (Şanlıurfa/Viranşehir örneği) [ The views of teachers' about 1mplementation of sound based sentence method in the first reading and writing education]. Adnan Menderes Üniversitesi Eğitim Fakültesi Eğitim Bilimleri Dergisi, 2(1), 27-37. Retrieved from https://dergipark.org.tr/en/download/article-file/399447

Albrecht, K. M., \& Miller, L. G. (2004). The comprehensive preschool curriculum. Beltsville, MD: Gryphon House, Inc.

Altun, D., \& Tantekin Erden, F. (2016). Okul öncesi öğretmen adaylarının erken okuryazarlık ile ilgili görüşleri ve staj uygulamaları [Pre-service preschool teachers' opinions and school practices on early literacy]. Ahi Evran Üniversitesi Eğitim Fakültesi Dergisi, 17(1), 241-261. Retrieved from https://dergipark.org.tr/en/download/article-file/1489163

Anthony, J. L., \& Francis, D. J. (2005). Development of phonological awareness. Current Directions in Psychological Science, 14(5), 255-259. https://doi.org/10.1111/j.0963-7214.2005.00376.x

Aydın, A., Edağ, C., \& Taş, N. (2011). 2003-2006 PISA okuma becerileri sonuçlarının karşıllaştırmalı olarak değerlendirilmesi: En başarılı beş ülke ve Türkiye [A comparative evaluation of PISA 2003-2006 results in reading literacy skills: An example of top-five OECD countries and Turkey]. Kuram ve Uygulamada Ĕ̈itim Bilimleri, 11(2), 651-673. Retrieved from https://openaccess.dpu.edu.tr/xmlui/bitstream/handle/20.500.12438/949/ayd\%c4\%b1n_ayhan.pdf?sequence $=1$ \&isAllowed $=\mathrm{y}$

Baş, Ö. (2006). Ses temelli cümle yöntemi ve bitişik eğik yazıyla okuma yazma öğretiminde alternatif harf siralaması [Alternative phonic sequence in literacy education with phonic based sentence method and contiguous inclined handwriting]. In Proceedings of International Congress of Profession of Classroom Teaching, Gazi University, Education Faculty 1, (pp. 215-554). Ankara: Kök Yayıncılık.

Başar, M. (2013). Okuma yazma öğrenerek ilkokula başlayan çocukların karşılaştıkları sorunların değerlendirilmesi [Evaluating the problems encountered by the students with emergent literacy]. EKEV Akademi Dergisi, 1(1), 275-294. Retrieved from http://www.ekevakademi.org/Makaleler/1379806421_15\%20Murat\%20BASAR.pdf

Başar, M. \& Tanış-Gürbüz, H. M. (2020). İlk okuma ve yazma öğretiminde karşılaşılan sorunlar ve çözüm önerileri [Problems encountered in literacy education and suggested solutions]. Okuma Yazma Eğitimi Araştırmaları, 8(1), 1-20. https://doi.org/10.35233/oyea.666563 
Başar, M., Doğan, M. C. \& Üstündağ-Şener, N. (2020). Okul öncesi dönemde kalem tutma etkinliklerinin ilk okuma yazma sürecine katkısı [The effect of pencil-holding activities in pre-school period on initial literacy process]. Uşak Üniversitesi Eğitim Araştırmaları Dergisi, 6(2), 44-62. Retrieved from https://dergipark.org.tr/en/download/article-file/1264973

Bay, N. D., \& Alisinanoğlu, F. (2008). Ana sınıfı öğretmenlerinin okuma yazmaya hazırlık çalışmalarına ilişskin yeterlilik algilarinin belirlenmesi [Determining sufficiency of kindergarten teachers regarding as preparation studies of reading-writing] (Unpublished master's thesis). Gazi University, Ankara.

Bodrova, E. \& Leong, D.J. (2007). Tools of the mind. The Vygotskian approach to early childhood education (2nd ed.). Ohio: Pearson, Pretice Hall.

Brown, J. K. (2008). Student-centered instruction: Involving students in their own education. Music Educators Journal, 94(5), 30-35. https://doi.org/10.1177/00274321080940050108

Burgess, S. R. (2002). The influence of speech perception, oral language ability, the home literacy environment, and pre-reading knowledge on the growth of phonological sensitivity: A one-year longitudinal investigation. Reading and Writing, 15(7-8), 709-737. https://doi.org/10.1023/A:1020954606695

Carneiro, P. \& Heckman, J. (2004). Human capital policy. Discussion paper no.821. Bonn: IZA.

Çelenk, S. (2008). İlköğretim okulları birinci sınıf öğrencilerinin ilkokuma ve yazma öğretimine hazırlık düzeyleri [Level of readiness for reading and writing education among first grade students of primary schools]. Abant İzzet Baysal Üniversitesi Eğitim Fakültesi Dergisi, 8(1), 83-90. Retrieved from https://dergipark.org.tr/en/download/article-file/16607

Cetin, O. S., Gulhan, M., \& Katranci, M. (2018). A study on the effect of pre-school education on early literacy skills. International Online Journal of Educational Sciences, 10(5), 201-221. https://doi.org/10.15345/iojes.2018.05.014

Cevher-Kalburan, F. N. (2010). Öykülerle alfabe [Alphabet with stories]. Ankara: Eğiten Kitap.

Creswell, J. W. (2013). Qualitative inquiry and research design: Choosing among five approaches (3rd ed.). New York: Sage.

Dankert, H., Davies, P. L., \& Gavin, W. J. (2003). Occupational therapy effects on visual-motor skills in preschool children. The American Journal of Occupational Therapy, 57(5), 542-549. https://doi.org/10.5014/ajot.57.5.542

Dennis, L. R., \& Horn, E. (2011). Strategies for supporting early literacy development. Young Exceptional Children,14(3), 29-40. https://doi.org/10.1177/1096250611420553

Dönmezler, E. (2016). Okul öncesi dönemde uygulanan okuma yazmaya hazırlık çalışmalarının öğretmen görüşlerine göre incelenmesi [Investigation of reading and writing studies applied in pre-school period 
according to teacher's views]. Turkish Journal of Primary Education, 1(1) 42-53. Retrieved from https://dergipark.org.tr/en/download/article-file/389313

Eminoğlu, N. \& Tanrıkulu, H. (2018). The research of the problems faced by the students who start primary school with the knowledge of reading and writing in regions of low socioeconomic status. Research in Reading \& Writing Instruction, 6(2), 56-69. Retrieved from https://dergipark.org.tr/tr/download/article-file/615014

Erdoğan, Ö. (2012). İlköğretim birinci sınıf öğrencilerinin fonolojik farkındalık becerileri ile okuma becerileri arasındaki ilişki [The relationship between the phonological awareness skills and reading skills of the first year students at primary school]. Eğitim ve Bilim, 37(166), 41- 51. Retrieved from http://eb.ted.org.tr/index.php/EB/article/view/1008/437

Erdoğan, T., Özen-Altınkaynak, Ş., \& Erdoğan, Ö. (2013). Okul öncesi öğretmenlerinin okuma-yazmaya hazırlığa yönelik yaptıkları çalışmaların incelenmesi [An analysis of the literacy activities provided by preschool teachers]. Illköğretim Online, 12(4), 1188-1199. Retrieved from https://web.p.ebscohost.com/ehost/pdfviewer/pdfviewer?vid=0\&sid=a7b1d98c-73e5-49e3-af5560bdce74735d\%40redis

Ergül, C., Karaman, G., Akoğlu, G., Tufan, M., Dolunay-Sarıca, A. \& Bahap-Kudret, Z. (2014). Okul öncesi öğretmenlerinin "Erken okuryazarlık" kavramına ilişkin bilgi düzeyleri ve sınıf uygulamaları [Early childhood teachers' knowledge and classroom practices on early literacy]. Illkögrretim Online, 13(4), 14491472. Retrieved from https://web.p.ebscohost.com/ehost/pdfviewer/pdfviewer?vid=0\&sid=700736c1-efca4d04-bf82-e05b3da13e70\%40redis

Genç-Ersoy, B. (2021). Stakeholder views on early literacy, reading and writing acquisition in the preschool period. Journal of Qualitative Research in Education, 9(1), 255-286. https://doi.org/10.14689/enad.25.11

Grunewald, R. (2018). Early childhood investments. Paving the way for the future workforce. In S. Andreason, T. Greene, H. Prince, \& C. E. Van Horn (Eds.) Investing America's workfoce. Improving outcomes for workers and employers, Vol 1, (pp. 297-314). Kalamazoo, MI: W.E. Upjohn Institute for Employment Research.

Gunn, B. K., Simmons, D. C. \& Kameenui, E. J. (2012). Emergent literacy: Instructional and curricular basics and implications. In D.C. Simmons, \& E.J. Kameenui, (Eds.), What reading research tells us about children with diverse learning need (pp. 51-60). New York: Routledge

Gürbüz, S., \& Şahin, F. (2016). Sosyal bilimlerde araştırma yöntemleri. Felsefe yöntem analiz [Research methods in social sciences. Philosophy method analysis] (3rd ed.). Ankara: Seçkin Yayıncılık.

Hanushek, E. and Wößmann, L. (2010). The economics of international differences in educational achievement. NBER Working Paper 15949, Cambridge, MA: National Bureau of Economic Research. 
Hattie, J. A. C. (2003). Teachers make a difference: What is the research evidence? Paper presented at the Building Teacher Quality: What does the research tell us. ACER Research Conference, Melbourne, Australia. Retrieved from http://research.acer.edu.au/research_conference_2003/4/.

HEC. (2018). Öğretmen yetiştirme lisans programlarl[Initial teacher education programs]. Ankara: Yüksek Öğretim Kurulu Başkanlığı. Retrieved from https://www.yok.gov.tr/Documents/Kurumsal/egitim_ogretim_dairesi/Yeni-Ogretmen-Yetistirme-LisansProgramlari/AA_Sunus \%200nsoz_Uygulama_Yonergesi.pdf.

HEC. (2020). YÖK’ten eğitim fakültelerinin müfredatlarına yönelik tarihi karar [Historical decision from HEC on the curricula of education faculties].Retrieved from https://www.yok.gov.tr/Sayfalar/Haberler/2020/egitimfak\%C3\%BCltelerine-yetki-devri.aspx.

Heckman, J. J. (2008). Schools, skills, and synapses. Economic Inquiry, 46(3), 289-324. https://doi.org/10.1111/j.1465-7295.2008.00163.x

Johnson, C. (2015). Concepts about the print and literacy skill acquisition of preschool students (Unpublished doctoral dissertation). Walden University, Minneapolis.

Kagan, S. L., \& Zigler, E. F. (Eds.). (1987). Early schooling: The national debate. New Haven, CT, US: Yale University Press.

Karagöl, E. (2018). Dil becerileri eğitimi açısından okul öncesi öğretmenliği lisans programı [Early childhood education program in terms of language skills education]. Academy Journal of Educational Sciences, 2(2), 159-171. Retrieved from https://www.ceeol.com/search/article-detail?id=791668.

McLaughlin, M. W. (1987). Learning from experience: Lessons from policy implementation. Educational Evaluation and Policy Analysis, 9(2), 171-178. https://doi.org/10.3102/01623737009002171

Miles, M, B., \& Huberman, A. M. (1994). Qualitative data analysis: An expanded sourcebook (2nd ed). Thousand Oaks, CA: Sage.

MoNE. (2013a). Okul öncesi eğitim programı. Ankara.

MoNE. (2013b). Çocuk gelişimi ve eğitimi: Okuma yazmaya hazırlı. Ankara.

MoNE. (2016). PISA 2015 ulusal raporu. Ankara: Milli Eğitim Bakanlığı. Retrieved from: http://odsgm.meb.gov.tr/test/analizler/docs/PISA/PISA2015_Ulusal_Rapor.pdf.

MoNE. (2018). Turkey's education vision2023. Retrieved from http://2023vizyonu.meb.gov.tr/doc/2023_VIZYON_ENG.pdf .

Morrow, L. M. (2001). Literacy development in the early years: Helping children read and write. In J. E. Many (Ed.), Handbook of instructional practices for literacy teachers-educators (1st ed.) (pp. 171-178). New York: RoutledgeOECD. (2017). Starting strong 2017: Key OECD indicators on early childhood education 
and care. Paris: OECD Publishing. Retrieved from: http://www.charlotte-buehler-institut.at/wpcontent/uploads/2017/10/Starting-Strong-2017.pdf.

OECD. (2019), PISA 2018 results (Volume I): What students know and can do. Paris: OECD Publishing, https://doi.org/10.1787/5f07c754-en

OECD. (2017). Starting strong 2017: Key OECD indicators on early childhood education and care. Paris: OECD Publishing. Retrieved from http://www.charlotte-buehler-institut.at/wp-content/uploads/2017/10/StartingStrong-2017.pdf

Oktay, A. (1999). Yaşamın sihirli yılları: Okul öncesi dönem [Magic years of life: Preschool period]. İstanbul: Epsilon Yayıncilık

Özcan, A. O., \& Özcan, A. F. (2014). Türk çocuklarının ses gelişim özellikleri ve ilk okuma yazma öğrenme [Sound developmental characteristics of Turkish children and literacy learning]. İstanbul Gelişim Üniversitesi Sosyal Bilimler Dergisi, 1(2), 67-86. https://doi.org/10.17336/igusbd.99559

Özdemir, Z. S., \& Bayraktar, A. (2015). Investigation of pre-service teachers' awareness regarding children's early literacy. Journal of Education and Future, (7), 37-48. Retrieved from https://dergipark.org.tr/en/download/article-file/174214

Pinto, G., Bigozzi, B., Gamannossi, B. A., \& Vezzani, C. (2009). Emergent literacy and learning to write: A predictive model for Italian language. European Journal of Psychology of Education, 14(1), 61-78. https://doi.org/10.1007/BF03173475

Pullen, P. C., \& Justice, L. M. (2003). Enhancing phonological awareness, print awareness, and oral language skills in preschool children. Intervention in School and Clinic, 39(2), 87-98. https://doi.org/10.1177/10534512030390020401

Ripley, A. (2010). What makes a great teacher?. The Atlantic, Education January/February. Retrieved from http://sdsuwriting.pbworks.com/f/What+Makes+a+Great+Teacher+-+Ripley.pdf.

Sever, S. (2004). Türkçe ögretimi ve tam öğrenme (4th ed.). Ankara: Anı Yayıncılık

Şahin, İ. T., Sak, R., \& Tuncer, N. (2013). Okul öncesi ve birinci sınıf öğretmenlerinin ilköğretime hazırlık sürecine ilişkin görüşlerinin karşılaştırılması [A comparison of preschool and first grade teachers’ views about school readiness]. Kuram ve Uygulamada Eğitim Bilimleri, 13(3), 1691-1713. Retrieved from https://app.trdizin.gov.tr/makale/TVRRM01UTTNOdz09/okul-oncesi-ve-birinci-sinif-ogretmenlerininilkogretime-hazirlik-surecine-iliskin-goruslerinin-karsilastirilmasi

Scarborough, H. S. (1998). Predicting the future achievement of second graders with reading disabilities: Contributions of phonemic awareness, verbal memory, rapid naming, and IQ. Annals of Dyslexia, 48(1), 115-136. Retrieved from https://link.springer.com/content/pdf/10.1007/s11881-998-0006-5.pdf 
Sonnenschein, S., \& Munsterman, K. (2002). The influence of home-based reading interactions on 5-year-olds' reading motivations and early literacy development. Early Childhood Research Quarterly, 17(3), 318-337. https://doi.org/10.1016/S0885-2006(02)00167-9

Tantekin-Erden, F., \& Altun, D. (2014). Sınıf öğretmenlerinin okul öncesi eğitim ve ilköğretime geçiş süreci hakkındaki görüşlerinin incelenmesi [An investigation of the opinions of primary school teachers' on preschool education and the transition process from preschool to primary school]. İlkögretim Online, 13(2), 481-502. Retrieved from https://web.p.ebscohost.com/ehost/pdfviewer/pdfviewer?vid=0\&sid=a75bfe483c48-40ec-ac30-0f3a996877dc\%40redis

Taşkın, N. (2014). İlkokula hazır olma [Be ready for primary school]. In F. Turan \& A. İ. Yükselen (Eds.), Çocuk gelişimi II [Child development II ](pp. 308-318). Ankara: Hedef Yayıncılık.

Taşkın, N., Katrancı, M., \& Uygun, M. (2014). Okul öncesi ve sınıf öğretmenlerinin okul öncesindeki okuma yazmaya hazırlık sürecine ilişkin görüşleri [The views of the preschool and primary school teachers on preparation process of emergent literacy in preschool]. Eğitimde Kuram ve Uygulama, 10(4), 1102-1119. Retrieved from https://dergipark.org.tr/tr/download/article-file/63385

Teddlie, C. \& Tashakkori, A. (2009). Foundations of mixed methods research: Integrating quantitative and qualitative approaches in the social and behavioral sciences. USA: SAGE Publications, Inc.

UNICEF. (2012). School readiness and transitions. A compainon of child friendly schools manual. New York: UNICEF, Division of Communication.

Üstün, E. (2007). Okul öncesi çocuklarının okuma yazma becerilerinin gelişimi [Development of preschool children's literacy skills]. İstanbul: Morpa Kültür Yayınları.

Whitehead, S. (2018). Preschool impact on emergent literacy in kindergarten students: A case study. (Doctoral dissertation). Miami University. Retrieved from https://etd.ohiolink.edu/apexprod/rws_etd/send_file/send?accession=miami1532347290748974\&dispositio $\underline{\mathrm{n}=\text { inline }}$

Wildová, R. \& Kropáčková, J. (2015). Early childhood pre-reading literacy development. Procedia-Social and Behavioral Sciences, 191(2015), 878-883.https://doi.org/10.1016/j.sbspro.2015.04.418

World Bank. (2009). Turkey: Expanding opportunities for the next generation. A report on life chances. Report No. 48627-TR. Washington D.C.: The World Bank.

Yapıc1, M., \& Ulu, F. B. (2010). First grade teachers' expectations from preschool teachers. Journal of Theoretical Educational Science, 3(1), 43-55. Retrieved from https://dergipark.org.tr/en/download/article-file/304128

Yıldırım, A. \& Şimşek, H. (2016). Sosyal bilimlerde nitel araştırma yöntemleri [Qualitative research methods in social sciences] (10th ed.). Ankara: Seçkin Yayıncılık. 
Yost, L. W. \& Lesiak, J. (2001). The relationship between performance on the developmental test of visual perception and handwriting ability. Education, 101(1), 75- 77. Retrieved from https://web.a.ebscohost.com/ehost/pdfviewer/pdfviewer?vid=0\&sid=a6402c43-85de-4b78-a440c0327a8b51cb\%40sessionmgr4007

Young, J.P. (2003). Predicting patterns of early literacy achievement: A longitudinal study of transition from home to school [Unpublished doctoral dissertation]. Griffith University, Australia.

Zygouris-Coe, V. (2001). Emergent literacy. Florida Literacy and Reading Excellence Center, Orlando: University of Central Florida, College of Education. Retrieved from, https://www.academia.edu/811485/Emergent_literacy.

\section{Corresponding Author Contact Information:}

Author name: Sabri Sidekli

Department: Department of Primary Education

Faculty: Faculty of Education

University, Country: Muğla Sttkı Koçman University, Turkey

Email: ssidekli@gmail.com

Please Cite: Başaran, S. T., \& Sidekli, S. (2021). The literacy preparation in Turkish preschool education. The European Educational Researcher, 5(1), 5-36. https://doi.org/10.31757/euer.511

Copyright: (C) 2022 EUER. This is an open-access article distributed under the terms of the Creative Commons Attribution License, which permits unrestricted use, distribution, and reproduction in any medium, provided the original author and source are credited. 